\title{
Kazus Alecka Bourne'a a konstytucyjne zasady ochrony życia i zdrowia
}

\section{Wprowadzenie}

Jedną ze specyficznych, właściwych dla bioetyki metod badawczych stała się analiza przypadków granicznych (ang. hard cases), na których tle rysują się podstawowe problemy etyczne $\mathrm{w}$ zakresie odnoszącym się do ludzkiego życia. Metoda ta wywodzi się z tradycji anglosaskich, niemniej wydaje się, że jest ona dość powszechnie akceptowana na gruncie bioetyki kontynentalnej, w tym również w Polsce. Filozoficznej podbudowy omawianej metody można poszukiwać w pismach Karla Jaspersa, którego zdaniem sytuacje graniczne stanowią treść egzystencji, uwypuklając fenomenologiczny stosunek do rzeczywistości ${ }^{1}$. Podobny stosunek do spraw granicznych prezentował też Ronald Dworkin, stwierdzając, że w przypadkach, w których obowiązujące przepisy prawa pozytywnego uchwalone przez uprawniony do tego organ nie zawierają dającej się zastosować jednoznacznej reguły prawnej, wówczas sędzia ma prawo zdecydować zgodnie z własnym przekonaniem ${ }^{2}$.

Podstawowym założeniem metody przypadków granicznych jest przedstawianie, w sposób niekiedy niezwykle szczegółowy, rzeczywistego przypadku medycznego, który stał się podstawą do rozstrzygnięcia sądowego. Następnie dokonywane są analizy stanowisk stron oraz

* Piotr Szudejko, dr, e-mail: kancelaria@szudejko.pl, https://orcid.org/0000-00025259-8759.

${ }^{1}$ K. Jaspers, Philosophy, t. 2, Chicago-London 1969-1970, s. 178-179.

${ }^{2}$ R. Dworkin, Taking Rights Seriously, London 1978, s. 81. 
samego rozstrzygnięcia w kontekście przyjmowanych założeń etycznych, co nasuwa skojarzenia z właściwą dla nauki prawa precedensowego analizą kazusów. W systemie prawa stanowionego precedensy nie stanowią co prawda samoistnych źródeł prawa, niemniej mają znaczący wpływ na kształtowanie linii orzecznictwa sądów. Szczególna jest natomiast rola precedensów w porządku prawnym Wspólnot Europejskich, a także w prawie międzynarodowym, w którym orzecznictwo sądowe uznawane jest za jedno ze źródeł prawa.

Metoda badania przypadków granicznych na gruncie polskiej bioetyki nie zawsze obejmuje pogłębioną analizę praktycznej przydatności określonego rozstrzygnięcia na gruncie polskiego porządku prawnego, co $\mathrm{w}$ pewnej mierze wynika $\mathrm{z}$ tego, że bioetycy nie zawsze posiadają stosowne przygotowanie prawnicze. Pogłębienie rozważań w kierunku analizy przepisów prawnych wydaje się jednak niezbędne do zastosowania metody badania przypadków granicznych, pozwala bowiem dokonywać oceny prawa obowiązującego oraz formułować wskazówki interpretacyjne bądź postulaty de lege ferenda. Należy zatem postulować podjęcie prób wyeliminowania tej zasadniczej słabości.

Barbara Chyrowicz, przedstawiając listę najistotniejszych dla rozwoju bioetyki wydarzeń, osiągnięć nauk biologiczno-medycznych oraz regulacji prawnych, wymieniła również katalog kazusów, które budząc ożywione niejednokrotnie emocje, sprowokowały do podejmowania rozważań nad właściwymi rozwiązaniami w zakresie bioetyki, w tym kazus Baby Doe czy kazus Karen Ann Quinlan³. Należy zauważyć, że większość autorów przedstawia zbliżony katalog kazusów stanowiących podstawę do problematyzacji i prowadzenia rozważań nad ich etycznymi i prawnymi aspektami. Takie przypadki należy zaliczyć do grupy zagadnień określanych jako bioetycznie czynne ${ }^{4}$.

Na tle powyższych, ogólnych stwierdzeń zdziwienie może budzić fakt, że podobnej analizie w polskiej literaturze przedmiotu nie został dotychczas poddany kazus doktora Alecka Bourne'a, który może stanowić istotny przyczynek do pogłębionych rozważań dotyczących granic dopuszczalności zabiegu przerywania ciąży.

Celem niniejszego artykułu jest zwięzłe przedstawienie stanu faktycznego oraz rozstrzygnięcia sądowego zapadłego w przedmiotowej w sprawie, a następnie podjęcie rozważań nad możliwością

\footnotetext{
${ }^{3}$ B. Chyrowicz, Bioetyka. Anatomia sporu, Kraków 2015, s. 17-38.

${ }^{4}$ J. Stelmach, Przyczyny sporów bioetycznych, w: Paradoksy bioetyki prawniczej, pod red. J. Stelmacha, B. Brożka, M. Soniewickiej, W. Załuskiego, Warszawa 2010, s. 15.
} 
wykorzystania wniosków wynikających z powyższego kazusu w polskim dyskursie bioetycznym nad konstytucyjną formą prawa do życia oraz prawa do ochrony zdrowia.

\section{Kazus doktora Alecka Bourne'a}

Budząca skrajne reakcje społeczne problematyka dopuszczalności przerywania ciąży stała się przedmiotem dość szczegółowych rozważań na gruncie polskiej jurysprudencji, podejmowanych głównie w latach dziewięćdziesiątych ubiegłego wieku. Wobec pojawiających się jednak obecnie postulatów nowelizacji Ustawy z dnia 7 stycznia 1993 r. o planowaniu rodziny, ochronie płodu ludzkiego i warunkach dopuszczalności przerywania ciąży ${ }^{5}$, a także w świetle niedawnego orzeczenia Trybunału Konstytucyjnego (TK) w sprawie K 1/20 z 22 października 2020 r. spodziewać się można ponownego ożywienia tej dyskusji.

Zasadniczo występują trzy modele regulacji prawnej w zakresie przerywania ciąży. Najdalej idącym modelem jest model dozwalający wykonanie takiego zabiegu na żądanie matki do określonego momentu zaawansowania ciąży, najczęściej mniej więcej do końca trzeciego miesiąca. Takie rozwiązanie zostało przyjęte na przykład w Szwecji, Zjednoczonym Królestwie czy Chinach. Przeciwne rozwiązanie obejmuje całkowity zakaz przerywania ciąży, połączony z jego penalizacją. Przykładem krajów, które wprowadziły całkowity zakaz aborcji, są Malta, Liechtenstein i Chile. Ponadto został wypracowany model wskazań, stanowiący rodzaj kompromisu pomiędzy tymi dwiema propozycjami regulacji. Zgodnie z modelem wskazań, przerwanie ciąży jest możliwe w ściśle określonych przypadkach, których wystąpienie musi zostać potwierdzone przez lekarza bądź organ państwa. Takimi wskazaniami są najczęściej: trudna sytuacja materialna lub osobista matki, zagrożenie jej życia lub zdrowia, pochodzenie ciąży z przestępstwa (najczęściej gwałtu lub kazirodztwa) oraz przesłanka embriopatologiczna, obejmująca występowanie ciężkich i nieodwracalnych wad rozwojowych płodu. Takie rozwiązanie zostało przyjęte na przykład w Japonii czy Argentynie. Należy przy tym zauważyć, że model wskazań, chociaż stanowi rodzaj kompromisu pomiędzy dwoma wcześniej przedstawionymi rozwiązaniami, które można określać jako skrajne, nie jest również wolny od słabości. Podstawowe znaczenie ma jego arbitralność, gdyż wychodząc

${ }^{5}$ Dz.U. 1993, Nr 17, poz. 78 ze zm., dalej „ustawa o planowaniu rodziny”. 
z założenia, że występuje konflikt pomiędzy dwoma uznawanymi za równorzędne prawami: matki do samostanowienia oraz zarodka lub płodu do życia, daje w określonych sytuacjach pierwszeństwu jednemu z nich ${ }^{6}$.

W polskim porządku prawnym przyjęty został model wskazań, przy czym w wyniku działalności negatywnego ustawodawcy - Trybunału Konstytucyjnego - dwie z czterech przyjętych początkowo w ustawie o planowaniu rodziny przesłanek zostały uznane za niekonstytucyjne, naruszające prawo do życia. Przedstawiona w uzasadnieniach obu orzeczeń argumentacja daje silne podstawy do domniemania, że w przypadku zgłoszenia stosownego wniosku także pozostałe przesłanki zostaną uznane za niekonstytucyjne, a nie nastąiło to dotychczas tylko z tego powodu, że TK jest związany granicami wniosku ${ }^{7}$. Nie odnosząc się do przedstawionej w uzasadnieniu orzeczenia etycznej argumentacji, należy zauważyć, że przyjęcie koncepcji, którą zdaje się postulować Trybunał, doprowadzi do rozległego konfliktu aksjologicznego w obrębie ustawodawstwa zwykłego. Uznanie zarodka i płodu za przedmiot ochrony równy człowiekowi urodzonemu spowoduje przede wszystkim niedającą się usunąć sprzeczność między przepisami ustawy karnej, które obecnie różnicują zagrożenie karne ze względu na etap rozwojowy, przewidując znacznie niższe kary za przerwanie ciąży niezgodnie $\mathrm{z}$ ustawą (art. $152 \S 1$ Kodeksu karnego ${ }^{8}$ przewiduje karę pozbawienia wolności do lat 3) niż za zabójstwo w typie podstawowym (art. 148 § 1 k.k. przewiduje karę pozbawienia wolności nie krótszą niż 8 lat, karę 25 lat pozbawienia wolności lub karę dożywotniego pozbawienia wolności). Takie rozróżnienie nie daje się obronić przy przyjęciu jednolitej ochrony dla człowieka urodzonego oraz nasciturusa.

Tłem dla przedstawianego kazusu doktora Alecka Bourne'a stała się historia czternastoletniej Milly Brown. W dniu 27 kwietnia 1938 r. dziewczynka stała się ofiarą zbiorowego gwałtu, popełnionego przez oficerów gwardii konnej. Okoliczności zajścia nie pozostawiały żadnych wątpliwości co do niedojrzałości, czy wręcz naiwności ofiary, którą sprawcy zwabili do opuszczonego końskiego boksu opowieścią o koniu,

${ }^{6}$ T. Pietrzykowski, Etyczne problemy prawa, Warszawa 2011, s. 134; K. Szczucki, Zagrożenie dla życia lub zdrowia kobiety jako przesłanki dopuszczajace przerwanie ciąży. Analiza stanu prawnego, w: Lege Artis - problemy prawa medycznego, pod red. J. Haberko, R. Kocyłowskiego, B. Pawelczyka, Poznań 2008, s. 102-112.

${ }^{7}$ Orzeczenie TK z 28 V 1997, sygn. K 26/96, OTK 1997/2/19; orzeczenie TK z 22 X 2020, sygn. K 1/20, M.P. 2021, poz. 114.

${ }^{8}$ Ustawa z dnia 6 czerwca 1997 r. - Kodeks karny (tekst jedn. Dz.U. 2020 poz. 1444), dalej: „k.k.". 
któremu miał wyrosnąć ogon w kolorze zielonym. Jak się okazało, w wyniku popełnionego przestępstwa nastolatka zaszła w ciążę. Rodzice dziewczynki byli od początku zdecydowani na dokonanie zabiegu przerwania ciąży, motywując to faktem, że ciąża pochodziła z gwałtu, oraz ze względu na psychiczną niedojrzałość swojej córki ${ }^{9}$.

Ochrona zarodka i płodu ludzkiego na gruncie ustawodawstwa Zjednoczonego Królestwa Wielkiej Brytanii i Irlandii Północnej była regulowana wówczas dwoma komplementarnymi względem siebie aktami prawnymi. Artykuł 58 ustawy z 1861 r. o przestępstwach na osobie $^{10}$ penalizował czyn polegający na bezprawnym wywołaniu poronienia oraz na dostarczeniu ciężarnej środków do jego wywołania, przewidując za oba te przestępstwa karę dożywotniego pozbawienia wolności. Uchwalona natomiast w 1929 r. ustawa o ochronie życia dzie$\mathrm{ci}^{11}$ penalizowała dodatkowo zniszczenie $\mathrm{w}$ trakcie porodu płodu zdolnego do żywego urodzenia, przy czym brytyjski ustawodawca określił, że zdolność do żywego urodzenia płód uzyskuje w 28 tygodniu ciąży. Jednocześnie wprowadzony został kontratyp, obejmujący dokonanie opisanego powyżej czynu w dobrej wierze, w celu zachowania życia matki. Powyższe okoliczności nie zostały jednak dokładniej zdefiniowane, a zatem ustawodawca dopuścił ich doprecyzowanie $w$ drodze wykładni sądowej, która w systemie prawa zwyczajowego stanowi samoistne źródło prawa.

Obowiązujące przepisy poddawane były publicystycznej krytyce, natomiast surowość kar oraz perspektywa odebrania prawa do wykonywania zawodu przyczyniały się do tego, że zabiegi przerywania ciąży przeprowadzane były co do zasady nielegalnie, w ramach tzw. podziemia aborcyjnego. W przedmiotowej jednak sprawie, ze względu na fakt prowadzenia postępowania karnego przeciwko sprawcom gwałtu oraz zainteresowanie prasy i opinii społecznej, rodzice Milly Brown nie mogli zdecydować się na takie rozwiązanie. Jedynym wyjściem stało się znalezienie lekarza, który zdecydowałby się na ryzyko wykonania zabiegu przerwania ciąży w sposób całkowicie jawny, mając świadomość późniejszego wszczęcia przeciwko sobie postępowania karnego. Lekarze, do których państwo Brown początkowo się zgłaszali, odmawiali

\footnotetext{
${ }^{9}$ J. Thorwald, Ginekolodzy, Warszawa 2016, s. 317-318.

${ }^{10}$ Offences Against the Person. Act 1861, https://www.legislation.gov.uk/ukpga/ Vict/24-25/100/contents (dostęp: 4 V 2021).

11 The Infant Life Act 1929, https://www.legislation.gov.uk/ukpga/Geo5/19-20/34/ section/1 (dostęp: 4 V 2021).
} 
wykonania zabiegu, powołując się między innymi na argument, że nie mogą pozbawić Anglii potencjalnego przyszłego premiera ${ }^{12}$.

Lekarzem, który ostatecznie zdecydował się przeprowadzić zabieg przerwania ciąży, był londyński ginekolog i położnik, syn pastora, Aleck Bourne. Poza wykonywaniem zawodu lekarza Bourne był zaangażowany w prowadzenie działalności społecznej w ramach Socjalistycznego Stowarzyszenia Medycznego oraz utworzonego w 1936 r. Stowarzyszenia na rzecz reformy prawa aborcyjnego. Zgodnie z poglądami wyrażanymi przez Bourne'a aborcja powinna być dopuszczalna wyłącznie wówczas, gdy jest to konieczne, natomiast obowiązujące prawo antyaborcyjne uznawał za niesprawiedliwe ${ }^{13}$. Poproszony o wykonanie zabiegu przerwania ciąży Bourne oświadczył, że decyzję może podjąć wyłącznie po osobistym zbadaniu pacjentki. Podczas badania ginekolog stwierdził, że stopień jej rozwoju oraz stan psychiki wskazuja, że przerwanie ciąży będzie korzystne dla jej zdrowia psychicznego.

W konsekwencji w dniu 14 czerwca 1938 r. Bourne przeprowadził zabieg wyłyżeczkowania macicy, o czym sam zawiadomił organy ścigania. Jego celem było zwrócenie uwagi opinii publicznej na fakt obowiązywania prawa, które było w jego ocenie niesprawiedliwe, a środkiem do realizacji tego celu stało się skierowanie przeciwko sobie postępowania karnego ${ }^{14}$. Sprawa tymczasem stała się głośna, powodując skrajne emocje. Nawet w dniu rozprawy A. Bourne otrzymał depeszę z życzeniami powodzenia od dość nieoczekiwanego nadawcy, mianowicie od Scotland Yardu ${ }^{15}$.

Obrońcą doktora przed sądem karnym Old Bailey został adwokat Roland Oliver. Ze względu na fakt przyznania się przez oskarżonego do popełnienia zarzucanego mu czynu oraz bezsporne wyjaśnienie wszelkich okoliczności sprawy, istotą postępowania stała się interpretacja obowiązujących przepisów, a zatem spór co do prawa. Kluczowa okazała się interpretacja dwóch terminów: użytego w ustawie o przestępstwach na osobie terminu bezprawnie oraz zastosowanego w ustawie o ochronie życia dzieci sformułowania życie matki. Już sama treść aktu oskarżenia uzasadniała przypuszczenie, że prokurator obawia

\footnotetext{
12 J. Hadley, Abortion: Between Freedom and Necessity, Philadelphia 1997, s. 35.

${ }^{13}$ C. de Costa, The King versus Aleck Bourne, "The Medical Journal of Australia” 2009, no. 191(4), s. 230-231.

${ }^{14}$ E. Cawthon, Medicine on Trial: A Handbook with Cases, Laws, and Documents, Santa Barbara 2004, s. 176-178.

${ }^{15}$ J. Thorwald, op. cit., s. 346.
} 
się skupienia rozważań na pierwszej z powyższych kwestii, w opisie kwalifikacji prawnej czynu zabrakło bowiem określenia bezprawnie. Obrońca zwrócił jednak uwagę sądu na powyższy brak, domagając się dokonania stosownego uzupełnienia. W odpowiedzi na to żądanie oskarżyciel stwierdził, że jest to frazes bez znaczenia, ponieważ w praktyce nie występują sytuacje, w których dokonanie zabiegu przerwania ciąży można uznać za postępowanie zgodne z prawem. W konsekwencji każdy zabieg przerwania ciąży musiałby zostać uznany za bezprawny. $Z$ taką oceną nie zgodził się jednak sąd orzekający, podnosząc, że każde pojęcie ustawowe musi mieć określone znaczenie. Wobec powyższego oskarżyciel ustąpił i uzupełnił akt oskarżenia o kontrowersyjne sformułowanie bezprawnie. Tym samym zostało przesądzone, że mogą występować takie okoliczności, w których doprowadzenie do poronienia pod rządami ówczesnych przepisów należało uznać za prawnie dopuszczalne, chociaż ustawodawca w żaden sposób takich przypadków nie sprecyzował.

Drugi argument obrony opierał się na przyjęciu rozszerzającej interpretacji pojęcia życie matki, które miało obejmować także jej zdrowie. Uzasadnieniem powyższej wykładni stało się twierdzenie, że utrata zdrowia w wyniku konieczności donoszenia ciąży może spowodować konsekwencję w postaci utraty przez kobietę życia w wyniku zamachu samobójczego. W przedmiotowej sprawie negatywny wpływ pochodzącej z przestępstwa ciąży na zdrowie psychiczne Milly Brown był bezsporny, o czym świadczył fakt, że nawet podczas nieinwazyjnego zabiegu pobrania wymazu z pochwy, przeprowadzanego przez doktora Bourne'a, dziewczynka wpadła w histerię. Wcześniej natomiast była hospitalizowana ze względu na omdlenie na tle nerwowym. W toku postępowania przesłuchano świadków obrony, w tym lekarzy ginekologów oraz psychiatrę, którzy zgodnie potwierdzili tezę o negatywnym wpływie ciąż pochodzących z gwałtu na zdrowie nieletnich ciężarnych zarówno psychiczne, jak i fizyczne, w tym ostatnim przypadku głównie z powodu niedostatecznego jeszcze rozwoju dróg rodnych ${ }^{16}$.

Po zakończeniu postępowania dowodowego, w końcowym pouczeniu dla ławy przysięgłych przewodniczący składu orzekającego sędzia Malcolm MacNaghten podkreślił, że przepisy prawne dopuszczają wykonanie zabiegu przerwania ciąży w sytuacji, w której zagrożone jest

${ }^{16}$ Rexv. Bourne (1939) 1 KB 687, https://www.law.utoronto.ca/utfl_file/count/documents/reprohealth/united_kingdom_1938_bourne.pdf (dostęp: 4 V 2021). 
życie matki. Jej życie polega natomiast na zdrowiu, przy czym nie jest konieczne, by lekarz zwlekał z podjęciem działań aż do ostatniej chwili, gdy życie pacjenta stanie się już bezpośrednio zagrożone. Jeśli zatem sędziowie przysięgli są przekonani, że oskarżony działał w zamiarze ratowania życia Milly Brown, wówczas powinni zdecydować o jego niewinności. Odnosząc się do religijnego kontekstu odmowy wykonania zabiegu przerwania ciąży, sędzia wspomniał również, że podobnie jak nie ma prawa umożliwiającego wykonanie aborcji na żądanie pacjentki, tak samo nie ma prawa zakazującego wykonania zabiegu ze względów religijnych, a zatem osoby, które na takie względy się powołują, nie powinny zostawać lekarzami ${ }^{17}$.

Po odbyciu narady ława przysięgłych podjęła decyzję o uniewinnieniu Alecka Bourne'a od zarzucanego mu czynu. Wybuch wojny uniemożliwił jednak przeprowadzenie liberalizacji przepisów prawa stanowionego w Zjednoczonym Królestwie. Nastąpiło to dopiero w 1967 r.

Dla zachowania uczciwości intelektualnej należy uczynić tutaj uwagę natury biograficznej: otóż po wojnie, w 1966 r. doktor Bourne zaangażował się w działalność Towarzystwa na rzecz ochrony nienarodzonych dzieci (SPUC), występując przeciwko liberalizacji prawa aborcyjnego. Tej zmiany jego poglądów nie należy jednak traktować jako przekreślenia znaczenia omawianego kazusu, gdyż podstawową w nim kwestią nie jest sam czyn oskarżonego czy też jego późniejszy stosunek psychiczny do tego czynu, ale sformułowana przez obronę i następnie przyjęta przez skład orzekający wykładnia obowiązującego prawa.

\section{Konstytucyjna forma prawa do życia i prawa do ochrony zdrowia}

Podejmując się oceny znaczenia omówionego kazusu na gruncie polskiego porządku prawnego oraz rozważając możliwość recypowania sformułowanych na jego podstawie wniosków, należy przede wszystkim rozważyć konstytucyjną formę prawa do życia oraz prawa do zdrowia.

Prawo do życia zostało sformułowane w art. 38 Konstytucji Rzeczypospolitej Polskiej z 1997 r. $^{18}$, zgodnie z którym Rzeczpospolita Polska

${ }^{17}$ B. Brookes, P. Roth, Rex v. Bourne and the Medicalization of Abortion, w: Legal Medicine in History, pod red. M. Clarka, C. Crawford, Cambridge 1994, s. 314-343.

${ }^{18}$ Konstytucja Rzeczypospolitej Polskiej z dnia 2 IV 1997 r. (Dz.U. Nr 78, poz. 483 ze zm.), dalej „Konstytucja RP”. 
zapewnia każdemu człowiekowi prawną ochronę życia. Ustrojodawca nie sprecyzował natomiast, na czym gwarantowana powyższym przepisem ochrona życia ma polegać, nie zdefiniował także momentu, w którym istota ludzka staje się podmiotem tej ochrony, ani też momentu i okoliczności, w którym taką ochronę traci.

Również ustawodawstwo zwykłe nie zawiera jednoznacznego przepisu, który określałby początek podmiotowości człowieka i uzyskanie pełnej ochrony prawnej. W tym zakresie brakuje też konsensusu w literaturze przedmiotu. Przeciwnie, na tym tle występuje dość silny spór pomiędzy przedstawicielami różnych stanowisk ${ }^{19}$. Najczęściej podnosi się, że początek podmiotowości człowieka wyznacza art. 8 Ustawy z dnia 23 kwietnia 1964 r. - Kodeks cywilny ${ }^{20}$ (kryterium urodzenia) bądź też że określają go przepisy art. 152-154 k.k. (kryterium biologiczne). Zgodnie z pierwszym z powyższych kryteriów człowiek jako podmiot praw i obowiązków powstaje w chwili urodzenia, a więc rozpoczęcia akcji porodowej bądź przystąpienia do zabiegu cięcia cesarskiego ${ }^{21}$. Przed tą chwilą zdolność prawna człowieka ma charakter niepełny, ponieważ obejmuje jedynie wprost wskazane prawa (np. może nabyć spadek na podstawie art. 927 $\S 2$ k.c.), które nasciturus może nabyć, a także warunkowy, gdyż uzależniona jest od urodzenia żywym. Drugie z powyższych kryteriów stanowi natomiast, że człowiek powstaje już w chwili połączenia dwóch gamet w zygotę, a więc od chwili zapłodnienia ${ }^{22}$. Ponadto istnieją jeszcze inne kryteria powstania człowieka, opierające się na zdarzeniach w rozwoju płodu, którym przypisuje się szczególne znaczenie dla jego bytu. Takimi kryteriami są: kryterium jednostkowienia, zdolności przeżycia poza organizmem matki, kryterium psychologiczne, neurologiczne czy społeczne.

W toczącym się w Polsce dyskursie najczęściej wywodzi się, że przyjęte w Konstytucji RP prawo do życia stanowi prawo podmiotowe ${ }^{23}$,

${ }^{19}$ A. Breczko, Podmiotowość prawna człowieka w warunkach postępu biotechnomedycznego, Białystok 2011, s. 191; A. Przyłuska-Fiszer, Etyka i przerywanie ciaży, w: Bioetyka, pod red. J. Różyńskiej, W. Chańskiej, Warszawa 2013, s. 311; W. Bołoz, Bioetyka i prawa człowieka, Warszawa 2007, s. 111.

${ }^{20}$ Tekst jedn. Dz.U. 2020, poz. 1740, dalej „k.c.”.

${ }^{21}$ Wyrok Sądu Najwyższego (SN) z 27 IX 2010 r., sygn. V KK 34/10, Legalis nr 271796; postanowienie SN z 30 X 2008 r., sygn. I KZP 13/08, Legalis nr 108372.

${ }^{22}$ A. Przyłuska-Fiszer, op. cit., s. 312; Jan Paweł II, Encyklika Evangelium Vitae, Rozdział III pkt 58, http://www.opoka.org.pl/biblioteka/W/WP/jan_pawel_ii/encykliki/ evangelium_1.html (dostęp: 4 V 2021).

${ }^{23}$ R. Grabowski, Prawo do ochrony życia w polskim prawie konstytucyjnym, Rzeszów 2006, s. 178-180. 
przysługujące istotom ludzkim od poczęcia aż do śmierci ${ }^{24}$, natomiast treść art. 8 k.c. wyznacza jedynie zdolność prawna, podczas gdy podmiotowość prawna nasciturusa jest odrębną kategoria, wywodzoną bezpośrednio z zasady godności, uregulowanej w art. 30 Konstytucji $\mathrm{RP}^{25}$. Interesującą koncepcją jest próba wyprowadzenia wniosku o podmiotowości embrionów i płodów z normy art. 68 ust. 3 Konstytucji RP, która przyznaje kobiecie ciężarnej podmiotowe prawo do szczególnej opieki zdrowotnej, które w istocie przysługiwać miałoby nasciturusowi ${ }^{26}$.

Podnoszone są jednak również głosy, że prawna ochrona życia, wyrażona $w$ art. 38 Konstytucji $R P$, nie oznacza $w$ istocie ochrony życia już od momentu poczęcia ${ }^{27}$ bądź też że ochrona embrionu i płodu ludzkiego powinna nasilać się wraz z rozwojem ciąży ${ }^{28}$, co zresztą znajduje odzwierciedlenie w regulacji karnej ${ }^{29}$.

Rozstrzygnięcie powyższych kontrowersji przekracza ramy niniejszego artykułu, należy natomiast zauważyć, że dodatkowych trudności interpretacyjnych dostarczają przepisy art. 23 ust. 3 oraz art. 83 Ustawy z dnia 25 czerwca 2015 r. o leczeniu niepłodności ${ }^{30}$, które odpowiednio zakazują niszczenia i penalizują niszczenie zarodków powstałych w wyniku medycznie wspomaganej prokreacji, które są zdolne do prawidłowego rozwoju. Za dopuszczalne bowiem należy uznać, wnioskując z przywołanych przepisów a contrario, zniszczenie zarodka niezdolnego do prawidłowego rozwoju. Powyższe przepisy otwierają drogę do wykładni zmierzającej do wyłączenia spod ochrony, którą postulują zwolennicy kryterium biologicznego, zarodków niezdolnych do prawidłowego rozwoju, powstałych w wyniku metod medycznie wspomaganej prokreacji, a więc do różnicowania ochrony zarodków w zależności od ich pochodzenia z procesów naturalnego bądź sztucznego zapłodnienia in vitro.

24 A. Zoll, Problemy służby zdrowia w świetle doświadczeń RPO, "Prawo i Medycyna” 2000, nr 8, s. 8.

${ }^{25}$ L. Bosek, Gwarancje godności ludzkiej i ich wptyw na polskie prawo cywilne, Warszawa 2012, s. 300-301.

${ }^{26}$ J. Haberko, Cywilnoprawna ochrona dziecka poczętego a stosowanie procedur medycznych, Warszawa 2010, s. 27.

${ }^{27}$ B. Banaszak, Komentarz do art. 38 Konstytucji RP, Legalis/el.; A.M. Kania, Z problematyki granic ochrony życia ludzkiego, "Wrocławskie Studia Erazmiańskie. Zeszyty Studenckie" 2009, nr 3, s. 102.

${ }^{28}$ O. Nawrot, Nienarodzony na ławie oskarżonych, Toruń 2007, s. 306.

${ }^{29}$ L. Paprzycki, Granice prawnokarnej ochrony życia i zdrowia człowieka na tle uchwały Sadu Najwyższego z 26 października 2006 r. (I KZP 18/06), „Prawo i Medycyna” 2007, nr 3, s. 56.

${ }^{30}$ Tekst jedn. Dz.U. 2020, poz. 442. 
Ustawodawca nie określił też jednoznacznego kryterium ustania człowieczeństwa, zawierając w art. 43a Ustawy z dnia 5 grudnia 1996 r. o zawodach lekarza i lekarza dentysty ${ }^{31}$ dwa kryteria stwierdzania zgonu, oparte na stwierdzeniu trwałego i nieodwracalnego ustania czynności mózgu (śmierci mózgu) oraz na stwierdzeniu nieodwracalnego ustania krążenia poprzedzającego pobranie narządów. Istnienie dwóch kryteriów dla stwierdzenia zgonu i ustania bytu człowieka stanowi trudną do zaakceptowania niekonsekwencję ustawodawcy, gdyż zastosowanie tych kryteriów może prowadzić do odmiennych wyników. Pośrednim skutkiem tej sytuacji jest trudność w jednoznacznym zdefiniowaniu prawa do życia i jego granic na gruncie polskich przepisów prawnych.

Prawo do życia stało się przedmiotem interpretacji Trybunału Konstytucyjnego. W kontrowersyjnym orzeczeniu z 28 maja 1997 r. (sygn. K 26/96) TK stwierdził, że prawo do życia ma charakter przyrodzony, niezależny od woli ustawodawcy, obejmując również nasciturusa, brak bowiem dostatecznie precyzyjnych naukowych kryteriów, które pozwalałyby na zróżnicowanie ochrony w zależności od stopnia rozwoju płodu ludzkiego. Nie mając charakteru bezwzględnego, ochrona życia ludzkiego powinna jednak spełniać warunek dostateczności. Do powyższego orzeczenia trzech sędziów zgłosiło zdania odrębne, zarzucając Trybunałowi tworzenie norm prawnych. W późniejszych orzeczeniach TK stwierdził, że prawo do życia składa się z dwóch elementów: zakazu pozbawiania życia oraz obowiązku podejmowania przez władze państwowe działań o charakterze ochronnym ${ }^{32}$.

W orzeczeniu z 22 października 2020 r. w sprawie K 1/20 Trybunał Konstytucyjny stwierdził natomiast, że obowiązkiem państwa jest ochrona życia człowieka, stanowiącego "centralne dobro przynależne każdemu człowiekowi", przy czym z godności człowieka wynika zakaz różnicowania wartości człowieka i jego życia. Również to orzeczenie można uznać za kontrowersyjne, ponieważ dwóch członków Trybunału złożyło zdania odrębne.

Z powyższej analizy wynika, że polski system prawny nie zawiera dostatecznie precyzyjnej definicji prawa do życia. Normy konstytucyjne i ustawodawstwo zwykłe nie określaja, na czym ma polegać prawna ochrona życia, ani tego, kto miałby być beneficjentem tej ochrony, a zwłaszcza w jakim zakresie miałaby przysługiwać człowiekowi

${ }^{31}$ Tekst jedn. Dz.U. 2021, poz. 790.

32 Wyrok TK z 23 III 1999 r., sygn. K 2/98, OTK 1999/3/38; wyrok TK z 30 IX 2008 r., sygn. K 44/07, Legalis nr 106699. 
w rozwoju płodowym. Zaprezentowana wykładnia TK ma charakter rozszerzający, obejmując obok urodzonych także nasciturusa, niemniej opiera się ona na założeniu, że nie istnieją kryteria naukowe, które pozwalałyby na zróżnicowanie ochrony płodu ludzkiego, co oznacza, iż rozwój nauki może spowodować zdezaktualizowanie tej wykładni.

Prawo do ochrony zdrowia określone zostało w art. 68 ust. 1 Konstytucji RP, zgodnie z którym każdy ma prawo do ochrony zdrowia. Kolejne ustępy tego artykułu stanowią, że władze zapewniają obywatelom równy dostęp do świadczeń opieki zdrowotnej, finansowanej ze środków publicznych (ust. 2), przy czym szczególną opiekę władze publiczne zobowiązane są zapewnić dzieciom, kobietom ciężarnym, osobom niepełnosprawnym i osobom w podeszłym wieku (ust. 3). Ponadto władze publiczne mają obowiązek zwalczania chorób epidemicznych, zapobiegania negatywnym dla zdrowia skutkom degradacji środowiska (ust. 4) oraz popierania rozwoju kultury fizycznej, w szczególności wśród dzieci i młodzieży (ust. 5). Podobnie jak w przypadku życia, definicja zdrowia nie została przez ustrojodawcę sformułowana, takiej definicji nie zawiera też ustawodawstwo zwykłe.

Na marginesie wypada $w$ tym miejscu poczynić uwagę, że istnieje wiele definicji zdrowia i choroby, z których dwie wydają się zasadnicze: koncepcja biostatyczna oraz koncepcja holistyczna. Pierwsza z nich opiera się na statystycznie występujących cechach organizmu i chorobę określa jako odstępstwa od normy. W przypadku powszechnego występowania pewnych odstępstw (np. skrzywienia kręgosłupa) koncepcja ta odwołuje się do funkcjonowania organizmu zgodnie $z$ jego przeznaczeniem $^{33}$. Koncepcja holistyczna natomiast uwzględnia subiektywny psychiczny stosunek osoby do określonego stanu jej zdrowia, choroba staje się zatem społecznym konstruktem społecznym, który nie musi być zgodny z normą wyznaczaną przez samą tylko biologię. W zależności od przyjętej definicji choroby zmienia się paradygmat i cel medycyny, który w przypadku przyjęcia koncepcji holistycznej uwzględnia aktywną rolę pacjenta w procesie leczenia i określenie pożądanego stanu zdrowia, do którego powinien dążyć lekarz ${ }^{34}$. Analiza obowiązujących przepisów nie daje jednoznacznej odpowiedzi na pytanie, którą z powyższych definicji wybrał polski ustawodawca. Model udzielania świadczeń zdrowotnych

${ }^{33}$ C. Boorse, On Distinction Between Disease and Illness, "Philosophy and Public Affairs" 1975, no. 5, s. 56.

${ }^{34}$ B. Fijałkowska, Teorie zdrowia i choroby, w: Bioetyka w zawodzie lekarza, pod red. W. Chańskiej, J. Hartmana, Warszawa 2010, s. 153-159. 
na podstawie wyrażonej przez pacjenta świadomej zgody (bądź wyrażenia takiej zgody przez uprawnioną do tego osobę lub organ w ramach zgody zastępczej) uzasadnia przypuszczenie, że polski system prawny uwzględnia przynajmniej częściowo subiektywny stosunek pacjenta do leczenia, właściwy dla koncepcji holistycznej.

Odnosząc się do kwestii ochrony zdrowia, Trybunał Konstytucyjny stwierdził, że art. 68 ust. 2 Konstytucji RP nakłada na władze publiczne obowiązek stworzenia systemu prawnego, który umożliwi dookreślenie treści prawa do ochrony zdrowia. Trybunał uznał również, że prawo do ochrony zdrowia ma "charakter normy programowej"35, natomiast jego treścią „nie jest abstrakcyjnie określony stan zdrowia poszczególnych jednostek, ale możliwość korzystania z systemu ochrony zdrowia, funkcjonalnie ukierunkowanego na zwalczanie i zapobieganie chorobom, urazom i niepełnosprawności"36.

Powyższe stwierdzenia dają asumpt do wysunięcia wniosku, że prawo do ochrony zdrowia nie jest uznawane przez TK za prawo o charakterze podmiotowym. Z powyższą interpretacją trudno się jednak zgodzić. Podkreślenia wymaga, że nie sposób utożsamiać prawa do ochrony zdrowia z prawem dostępu do świadczeń zdrowotnych, finansowanych ze środków publicznych. Prawa te nie tylko zostały odrębnie uregulowane, ale przede wszystkim mają odmienny krąg adresatów. Prawo do ochrony zdrowia, zgodnie z brzmieniem art. 68 ust. 1 Konstytucji RP, przysługuje bowiem każdemu, natomiast prawo dostępu do świadczeń zdrowotnych, finansowanych ze środków publicznych, zrekonstruowane z treści art. 68 ust. 2 ustawy zasadniczej, obejmuje wyłącznie obywateli ${ }^{37}$. Tym samym utożsamianie tych dwóch praw trzeba uznać za bezpodstawne. Na marginesie należy przy tym zauważyć, że sformułowanie każdy, zastosowane w komentowanym przepisie, nie jest tożsame z określeniem każdy człowiek, użytym w art. 38 Konstytucji RP, co trzeba uznać za błąd ustrojodawcy, polegający na niekonsekwencji terminologicznej. Trudno bowiem przypuszczać, by zamiarem racjonalnego ustawodawcy było wyposażenie niebędących ludźmi osób ${ }^{38} \mathrm{w}$ prawo do ochrony zdrowia, nie zapewniając im jednak prawa do ochrony życia.

${ }^{35}$ Wyrok TK z 24 II 2004 r., sygn. K 54/02, Legalis nr 61354.

${ }^{36}$ Wyrok TK z 29 IX 2015 r., sygn. K 14/14, Legalis nr 1336427; wyrok TK z 23 III 1999 r., sygn. K 2/98, OTK 1999/3/38; wyrok TK z 7 I 2004 r., sygn. K 14/03, Legalis nr 60760.

${ }^{37}$ L. Bosek, Komentarz do art. 68, w: Konstytucja RP, t. 1: Komentarz do art. 1-86, pod red. M. Safjana, L. Boska, Legalis/el.

${ }^{38}$ P. Singer, Wyzwolenie zwierzat, Warszawa 2004, s. 16-19. 
Należy się natomiast skłonić do wniosku, że prawo do ochrony zdrowia jest prawem podmiotowym, przysługującym każdemu człowiekowi, natomiast sposobem jego realizacji jest spoczywający na władzy państwowej obowiązek ukształtowania systemu opieki zdrowotnej, finansowanej ze środków publicznych na zasadzie równości dostępu do tych świadczeń, z uwzględnieniem wyjątków wskazanych w art. 68 ust. 3 ustawy zasadniczej. Za takim wnioskiem przemawia wykładnia systemowa. Artykuł 68 został bowiem zamieszczony w rozdziale zatytułowanym "Wolności i prawa ekonomiczne, socjalne i kulturalne". Ponadto wniosek ten uzasadnia podobieństwo do innych, określonych w tym samym rozdziale praw, np. prawa do wolności wyboru i wykonywania zawodu (art. 65 ust. 1).

Jak już wspomniano, w systemie prawa stanowionego orzeczenia sądów co do zasady nie są uznawane za źródła powszechnie obowiązującego prawa. Wyjątki dotyczą sądów ustanowionych w prawie wspólnot europejskich, a także Trybunału Konstytucyjnego, który pełniąc rolę tzw. negatywnego ustawodawcy oraz wydając orzeczenia interpretacyjne, wpływa na treść norm prawnych. Wiążące, niemniej tylko w danej sprawie, są też orzeczenia Sądu Najwyższego.

Truizmem jest stwierdzenie, że wyrok w sprawie doktora Alecka Bourne'a nie może być uznany za źródło prawa, zwłaszcza prawa obowiązującego w innym kraju. Niemniej zaproponowana przez obrońcę i przyjęta przez skład orzekający wykładnia może stanowić podstawę do podjęcia rozważań nad treścią przyjętych w polskiej ustawie zasadniczej praw: do życia oraz do ochrony zdrowia.

Z przedstawionych rozważań wynika, że obydwa te prawa mają charakter praw podmiotowych, przysługujących każdemu człowiekowi. Ich korelatem są określone obowiązki władz państwowych. $Z$ analizy wykładni Trybunału Konstytucyjnego wynika natomiast, że do obowiązków tych należą: powstrzymanie się od pozbawiania życia, podejmowanie działań zmierzających do ochrony życia, a także ukształtowanie systemu udzielania świadczeń zdrowotnych w sposób, który zapewnia zwalczanie i zapobieganie chorobom, urazom i niepełnosprawności.

Należy stwierdzić, że wskazane obowiązki, w szczególności należące do dwóch ostatnich kategorii, pozostają ze sobą nierozerwalnie związane. $Z$ jednej strony nie ulega bowiem wątpliwości, że działania mające chronić ludzkie życie obejmują również ochronę przed czynnikami chorobotwórczymi czy też innymi zagrożeniami, które poprzez 
pogorszenie stanu zdrowia mogą doprowadzić do śmierci (np. zagrożeniami wynikającymi z pracy w warunkach niebezpiecznych). $Z$ drugiej natomiast zaniedbania państwa w zakresie właściwego ukształtowania systemu opieki zdrowotnej mogą być uznane za narażenie, czy wręcz w skrajnych przypadkach spowodowanie śmierci człowieka.

Próba dokładnego rozdzielenia zadań publicznych na te, które służą wyłącznie ochronie życia człowieka, i te, które służą wyłącznie ochronie jego zdrowia, wydaje się zatem skazana na niepowodzenie. Życie człowieka w wymiarze biologicznym sprowadza się wszakże do dobrego stanu jego zdrowia, a różnica pomiędzy życiem a zdrowiem ma charakter wyłącznie ilościowy, nie zaś jakościowy. Tym samym aktualna pozostaje przyjęta w sprawie Alecka Bourne'a teza, że w określeniu życie matki mieści się także jej zdrowie zarówno fizyczne, jak i psychiczne. Ekstrapolując ten argument, w terminie życie człowieka można poszukiwać również jego zdrowia.

W konsekwencji, przyjmując taką interpretację, za błędne należy uznać rozdzielenie $\mathrm{w}$ art. 4 a ust. 1 pkt 1 ustawy o planowaniu rodziny kategorii zdrowia i życia kobiety ciężarnej jako wskazań do przeprowadzenia zabiegu przerwania ciąży, skoro wystarczające byłoby zastosowanie terminu zdrowie.

Na gruncie konstytucyjnym brak natomiast podstaw do hierarchizacji prawa do życia i prawa do ochrony zdrowia, gdyż obydwa te prawa podmiotowe są ze sobą treściowo powiązane w sposób nierozerwalny. Prawo do ochrony zdrowia jest niezbędnym środkiem realizacji prawa do życia, bez zapewnienia prawa do życia nie sposób zaś uzasadnić przyznania prawa do świadczeń zdrowotnych, co zostało wykazane na przykładzie wykładni użytych przez ustrojodawcę sformułowań każdy oraz każdy człowiek.

Dopuszczalność przerywania ciąży na podstawie modelu wskazań stanowi sposób normatywnego rozstrzygnięcia konfliktu wartości, zachodzącego pomiędzy prawem zarodka oraz płodu do życia a prawami kobiety ciężarnej. W polskim porządku prawnym są to obecnie: prawo do życia oraz prawo do ochrony zdrowia. Osobno występuje trzecia przesłanka, uwzględniająca zapobieganie skutkom przestępstwa, w tym również dla zdrowia ciężarnej. Sposób rozstrzygnięcia powyższego konfliktu wzbudzał i nadal wzbudza kontrowersje, stanowi bowiem miejsce przecięcia się wielu płaszczyzn: normatywnej, etycznej, religijnej czy medycznej. Z tych powodów nie wydaje się możliwe 
wypracowanie rozwiązania prawnego, które byłoby akceptowalne dla wszystkich adresatów norm. W tej sytuacji szczególnego znaczenia nabiera sądowa wykładnia przepisów o przerywaniu ciąży mogąca spowodować złagodzenie przepisów prawnych, które ze względu na treść wyroku Trybunału Konstytucyjnego w sprawie K 1/20 uległy zaostrzeniu. Właściwe wydaje się w tej sytuacji uwzględnianie zarówno przez lekarzy, jak i wymiar sprawiedliwości kwestii zdrowia kobiety ciężarnej, w tym jej zdrowia psychicznego, zwłaszcza w warunkach ciąży niechcianej. W omówionym kazusie dość wyraźnie wskazano na to, że zagrożenie zdrowia psychicznego może doprowadzić nawet do śmierci poprzez podjęcie próby samobójczej, i teza ta do dziś zachowuje swoją aktualność.

\section{Podsumowanie}

Bioetyka jest nauką stosunkowo młoda, w związku z czym naturalne jest korzystanie z dorobku metodologicznego innych dyscyplin naukowych, w szczególności filozofii, etyki i prawa. Metodą zapożyczoną $\mathrm{z}$ angielskiej jurysprudencji, którą wykorzystują również polscy badacze, jest metoda analizy przypadków granicznych, w których uwypukla się problematyka związana z szeroko pojętym wpływem rozwoju biologii oraz medycyny na życie człowieka.

Zasadne wydaje się postulowanie włączenia do polskich rozważań bioetycznych kazusu doktora Alecka Bourne'a, co pozwoli na wykorzystanie dorobku angielskiej jurysprudencji do analiz polskich rozwiązań ustawowych w kontekście konstytucyjnych zasad prawa do życia i do ochrony zdrowia. Przedmiotowy kazus stał się jednym z bodźców do znowelizowania obowiązujących w Zjednoczonym Królestwie przepisów, co do których zgłaszano zastrzeżenie, że nie odpowiadają już społecznemu zapotrzebowaniu. Jednocześnie był to z całą pewnością jeden z omówionych we wstępnej części artykułu przypadków granicznych, w których rozstrzygnięcie sądu oparło się na dynamicznej wykładni obowiązujących przepisów oraz w dużej mierze na władzy dyskrecjonalnej sędziego. Można przypuszczać, że także w Polsce podobne orzeczenia sądowe, uwzględniające dynamiczną wykładnię przepisów w duchu społecznego zapotrzebowania, będą dawały asumpt do stosownej reakcji ustawodawcy. 
Możliwa wydaje się próba przeniesienia do rodzimego dyskursu argumentu o jakościowej tożsamości zdrowia oraz życia, w których różnica występuje jedynie w zakresie ilościowym. W konsekwencji można wyprowadzić wniosek, że również prawo do życia oraz do ochrony zdrowia są treściowo, nierozerwalnie powiązane ${ }^{39}$.

Przyjęcie takiej koncepcji może ułatwić rozstrzyganie wątpliwości mogących powstać na tle stosowania przesłanek przerywania ciąży, w szczególności określonej w art. 4a ust. 1 pkt 1 ustawy o planowaniu rodziny. Może też przyczynić się do upowszechnienia właściwej wykładni konstytucyjnego prawa do ochrony zdrowia jako prawa podmiotowego, nie zaś wyłącznie jako rodzaju dyrektywy programowej, wskazówki dla organów państwa odpowiedzialnych za konstrukcję systemu ochrony zdrowia.

\section{THE CASE OF ALECK BOURNE AND THE CONSTITUTIONAL PRINCIPLES OF LIFE AND HEALTH PROTECTION}

\section{Sum mary}

The article presents the case of Dr. Aleck Bourne, which the author proposes to include in the catalog of borderline cases constituting the basis for in-depth discussions on ethical and legal aspects of human life with regard to the development of biology and medicine.

The starting point is the presentation of the worldwide models for regulating the practice of abortion as well as the Polish regulation, together with a discussion on the role of the Constitutional Tribunal in shaping current legal provisions. The author notes that the interpretation of the right to life adopted by the Tribunal encourages the repeal of the indication model and the introduction of a complete ban on abortion, which will have significant consequences for ordinary legislation.

Apart from describing the facts in the Bourne case, the strategy adopted by the defense and the sentence itself, the possible further areas of considerations regarding the limits of permissibility of termination of pregnancy have been signaled. Then, the conclusions resulting from legal analysis of the case were transferred to the exegesis of the constitutional principles of the right to life and the right to healthcare. Their constitutional form, interpretation resulting from the rulings of the Constitutional Tribunal and the ordinary legislation have been presented. The author indicates the main terminological deficiencies identified in this respect: the lack of any definition of the beginning of a human being, the existence of two separate criteria for determining death, which could lead to different results and the lack of an unambiguous definition of disease adopted by the legislator. Based on

${ }^{39}$ T. Sroka, Komentarz do art. 38, w: Konstytucja RP, t. 1: Komentarz do art. 1-86, pod red. M. Safjana, L. Boska, Legalis/el. 
the concepts presented in the case, the right to healthcare has been defined as a legal right resulting from the right to life. The final thesis is that there are no grounds for hierarchizing these rights, as they are intertwined in content and function.

Keywords: right to live - right to healthcare - abortion - hard cases

\section{LITERATURA}

Banaszak B., Komentarz do art. 38 Konstytucji RP, Legalis/el.

Bołoz W., Bioetyka i prawa człowieka, Warszawa 2007.

Boorse C., On Distinction Between Disease and Illness, "Philosophy and Public Affairs" 1975 , no. 5 .

Bosek L., Gwarancje godności ludzkiej i ich wpływ na polskie prawo cywilne, Warszawa 2012.

Bosek L., Komentarz do art. 68, w: Konstytucja RP, t. 1: Komentarz do art. 1-86, pod red. M. Safjana, L. Boska, Legalis/el.

Breczko A., Podmiotowość prawna człowieka w warunkach postępu biotechnomedycznego, Białystok 2011.

Brookes B., Roth P., Rex v. Bourne and the Medicalization of Abortion, w: Legal Medicine in History, pod red. M. Clarka, C. Crawford, Cambridge 1994.

Cawthon E., Medicine on Trial: A Handbook with Cases, Laws, and Documents, Santa Barbara 2004.

Chyrowicz B., Bioetyka. Anatomia sporu, Kraków 2015.

Costa de C., The King versus Aleck Bourne, "The Medical Journal of Australia" 2009, no. 191(4).

Dworkin R., Taking Rights Seriously, London 1978.

Fijałkowska B., Teorie zdrowia i choroby, w: Bioetyka w zawodzie lekarza, pod red. W. Chańskiej, J. Hartmana, Warszawa 2010.

Grabowski R., Prawo do ochrony życia w polskim prawie konstytucyjnym, Rzeszów 2006.

Haberko J., Cywilnoprawna ochrona dziecka poczętego a stosowanie procedur medycznych, Warszawa 2010.

Hadley J., Abortion: Between Freedom and Necessity, Philadelphia 1997.

Jan Paweł II, Encyklika Evangelium Vitae, http://www.opoka.org.pl/biblioteka/W/ WP/jan_pawel_ii/encykliki/evangelium_1.html.

Jaspers K., Philosophy, t. 2, Chicago-London 1969-1970.

Kania A.M., Z problematyki granic ochrony życia ludzkiego, „Wrocławskie Studia Erazmiańskie. Zeszyty Studenckie" 2009, nr 3.

Nawrot O., Nienarodzony na ławie oskarżonych, Toruń 2007.

Paprzycki L., Granice prawnokarnej ochrony życia i zdrowia człowieka na tle uchwały Sądu Najwyższego z 26 października 2006 r. (I KZP 18/06), "Prawo i Medycyna” 2007, nr 3.

Pietrzykowski T., Etyczne problemy prawa, Warszawa 2011.

Przyłuska-Fiszer A., Etyka i przerywanie ciaży, w: Bioetyka, pod red. J. Różyńskiej, W. Chańskiej, Warszawa 2013. 
Rex v. Bourne (1939) 1 KB 687, https://www.law.utoronto.ca/utfl_file/count/documents/reprohealth/united_kingdom_1938_bourne.pdf (dostęp: 4 V 2021).

Singer P., Wyzwolenie zwierząt, Warszawa 2004.

Sroka T., Komentarz do art. 38, w: Konstytucja RP, t. 1: Komentarz do art. 1-86, pod red. M. Safjana, L. Boska, Legalis/el.

Stelmach J., Przyczyny sporów bioetycznych, w: Paradoksy bioetyki prawniczej, pod red. J. Stelmacha, B. Brożka, M. Soniewickiej, W. Załuskiego, Warszawa 2010.

Szczucki K., Zagrożenie dla życia lub zdrowia kobiety jako przesłanki dopuszczajace przerwanie ciaży. Analiza stanu prawnego, w: Lege Artis - problemy prawa medycznego, pod red. J. Haberko, R. Kocyłowskiego, B. Pawelczyka, Poznań 2008.

Thorwald J., Ginekolodzy, Warszawa 2016.

Zoll A., Problemy stużby zdrowia w świetle doświadczeń RPO, „Prawo i Medycyna” 2000, nr 8. 


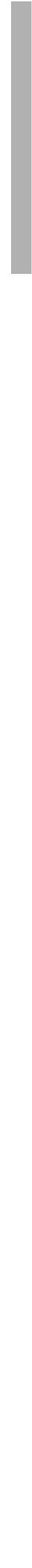

